網膜循環系における retinal ischemie と 過酸化脂質の意義 (1)

—とくに糖尿病性網膜について——

$$
\begin{array}{llllll}
\text { 石 } & \text { 清* } & \text { 忍 } & \text { 足 } & \text { 正 } \\
\text { 千 } \\
\text { 葉 }
\end{array}
$$

\title{
Lipoperoxides and retinal ischemia in diabetic retinopathy (1)
}

\author{
Kiyoshi ISHIKAWA*, Masayuki OSHITARI*, \\ Jiro CHIBA* and Yohko SHIMANO*
}

Key words : Diabetes, Retinopathy, Ischemia Lipoperoxides

Seven patients with progressive diabetic retinopathy developed extensive retinal areteriolar and capillary obstruction.

The clinical features shared to some extent by all of these patients were summarized as follows ;

1) Retinal edema, haemorrhages and soft exudates were observed in all cases and thread-like arterioles in 4 cases.

2) Arterial vascular disease was complicated in 6 of 7 cases.

3) Loss of visual acuity in all cases and usually visual loss may be of sudden onset.

4) Visual field defects also were seem in all cases, central and paracentral scotomas corresponded to the areas of retinal ischemia.

5) Optic disc pallor and neovascularization of the optic disc was seen in 4 of 7 cases.

6) Retinal ischemia was especially severe at the posterior pole. Fluorescein angiogram showed severe arteriolar and capillary obliteration.

7) Granular blood flow was observed in some cases showing severe retinal vascular stasis.

8) Higher platelet aggregation enhancing activity and Malondialdehyde value in the plasma was found in all subjects than in the normals.

9) These findings may suggest the retinal intravascular coagulation syndrom.

はじめに

糖尿病性網膜症 (以下単に網膜症こ略) にお ける retinal ischemie は検眼鏡ないし眼底写真
からでは確認されず蛍光眼底によって始めて毛 細血管閉塞による micro retinal ischemie とし て蛍光充盈のみられないととによって確認され る。

* 千葉大学医学部眼科 〔干280 千葉市亥鼻1-8-1], Department of Ophthalmalogy, Chiba University School of Medicine, Chiba, Japan. 
Table 1 Ischemic diabetic retinopathy

\begin{tabular}{|c|c|c|c|c|c|c|c|c|c|c|c|}
\hline \multirow{2}{*}{$\begin{array}{l}\text { Patient } \\
\text { Age } \\
\text { (yr) } \\
\text { Sex }\end{array}$} & \multirow{2}{*}{$\begin{array}{c}\text { Duration } \\
\text { of } \\
\text { diabetes }\end{array}$} & \multirow{2}{*}{$\begin{array}{l}\text { Visual } \\
\text { acuity }\end{array}$} & \multicolumn{2}{|l|}{ Optic } & \multirow{2}{*}{$\begin{array}{l}\text { Rubeosis } \\
\text { retinde }\end{array}$} & \multicolumn{2}{|c|}{$\begin{array}{l}\text { White threadlike } \\
\text { arterie }\end{array}$} & \multirow{2}{*}{$\begin{array}{l}\text { Retinal } \\
\text { hemorr } \\
\text {-hage }\end{array}$} & \multirow{2}{*}{$\begin{array}{c}\text { soft } \\
\text { exudate }\end{array}$} & \multirow{2}{*}{$\begin{array}{l}\text { Stage } \\
(\text { Scott })\end{array}$} & \multirow{2}{*}{$\begin{array}{l}\text { Ocular } \\
\text { tenion }\end{array}$} \\
\hline & & & Pallor & $* \mathrm{NV}$ & & OD & OS & & & & \\
\hline 168 今 & 11 & $\begin{array}{l}0.3 \\
0.3\end{array}$ & - & - & + & + & + & + & + & III $b$ & normal \\
\hline 253 & 15 & $\begin{array}{l}0.02 \\
0.04\end{array}$ & + & + & + & + & + & + & + & III b & "I \\
\hline 358 우 & 20 & $\begin{array}{l}0.7 \\
0.2 \\
\end{array}$ & - & - & - & - & - & + & + & III $b$ & "I \\
\hline 462 今 & 12 & $\begin{array}{l}0.6 \\
0.06\end{array}$ & + & $\bar{t}$ & + & + & + & + & + & III b & "I \\
\hline 556 今 & 13 & $\begin{array}{l}0.6 \\
0.04\end{array}$ & - & $\overline{+}$ & + & - & - & + & + & III b & " \\
\hline 656 今 & 4 & $\begin{array}{l}0.4 \\
0.4\end{array}$ & - & - & - & - & - & + & + & III b & " \\
\hline 760 今 & 11 & $\begin{array}{l}0.7 \\
0.02\end{array}$ & - & $\overline{+}$ & - & - & + & + & + & III $b$ & "I \\
\hline
\end{tabular}

Table 2 Ischemic diabetic retinopathy

\begin{tabular}{c|c|c|c|c|c|c|c}
\hline ¿Patient & $\begin{array}{c}\text { B } \cdot \text { P. } \\
(\mathrm{mmHg})\end{array}$ & Protein.urie & Control & $\begin{array}{c}\text { t-Choles } \\
\text {-terol } \\
(\mathrm{mg} \%)\end{array}$ & $\begin{array}{c}\text { Serum } \\
\text { criatinin } \\
(\mathrm{mg} \%)\end{array}$ & $\begin{array}{c}\text { BUN } \\
\text { (mg\%) }\end{array}$ & $\begin{array}{c}\text { Platelet } \\
\text { aggregation }\end{array}$ \\
\hline 1 & $200 \sim 90$ & H & fair & 269 & 1.2 & 20 & $\uparrow \uparrow$ \\
\hline 2 & $156 \sim 110$ & + & fair & 188 & 0.9 & 28 & $\uparrow \uparrow$ \\
\hline 3 & $180 \sim 100$ & - & fair & 267 & 1.2 & 18 & $\uparrow \uparrow$ \\
\hline 4 & $160 \sim 90$ & + & good & 140 & 1.0 & 26 & $\uparrow \uparrow$ \\
\hline 5 & $142 \sim 86$ & - & good & 137 & 0.8 & 18 & $\uparrow$ \\
\hline 6 & $142 \sim 90$ & \pm & fair & 180 & 0.9 & 12 & $\uparrow$ \\
\hline 7 & $170 \sim 90$ & + & poor & 190 & 0.7 & 11 & $\uparrow$ \\
\hline
\end{tabular}

しかもこれが多発は網膜の hypoxic ないし anoxic process を増強させ病変増悪の重要な要 因と考えられている.

一方本網膜症における広範かつ大きい retinal ischemie の存在についてはあまり報告されてお らず最近では Bresnik 等の報告に接する.

今回著者らはかかる症例 7 例を経験し血小板 凝集能および過酸化脂質の面から検討し，いさ さか興味ある結果を得たので，ここに報告す る.
1）症例は表 1 に示したごとく 7 例で男子 6 名, 女子 1 名で男子に多く, 年齢は全例 50 歳以 上, 糖尿病罹病期間は 1 例を除き 10 年以上であ った. 視力は $0.02 \sim 0.7$ の間に分布しているが 概して中等度に障害され 0.4 以下の屯のが 14 眼 中10眼を占めている.

血小板凝集能拉よび血中過酸化脂質の測定法 はすでに発表したごとく安永氏法および安藤氏 変法に従った。過酸化脂質は Malondialahid (以 下 MDA と略) として測定した。

2）眼底所見の共通点

表 1 からあ分るごとくこれらの症例には多く

\section{I. 実験対象並びに実験方法}




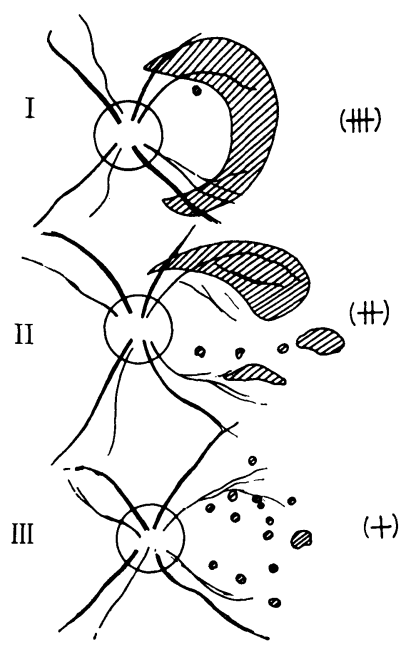

Fig. 1 Schema of ischemic areas and grading

Table 3 Ischemic diabetic retinopathy

\begin{tabular}{|c|c|c|c|c|c|c|}
\hline & $\begin{array}{l}\text { Patien } \\
\text { Age } \\
\text { (yr) } \\
\text { Sex }\end{array}$ & $\begin{array}{c}\text { Duration } \\
\text { of } \\
\text { diabetes } \\
\text { (yr) }\end{array}$ & $\begin{array}{l}\text { Visual } \\
\text { acuity }\end{array}$ & $\begin{array}{l}\text { Grading of isch } \\
\text { emicretinal } \\
\text { area }\end{array}$ & $\begin{array}{l}\text { Platelet aggre- } \\
\text { gation activity } \\
(\%)\end{array}$ & $\begin{array}{c}\text { MDA } \\
\text { n moles/ml }\end{array}$ \\
\hline 1 & 68 今 & 11 & $\begin{array}{l}0.3 \\
0.2\end{array}$ & H & 80.2 & 14.87 \\
\hline 2 & 53 今 & 15 & $\begin{array}{l}0.02 \\
0.04\end{array}$ & H & 69.7 & 13. 92 \\
\hline 3 & 58 우 & 20 & $\begin{array}{l}0.7 \\
0.2\end{array}$ & $H$ & 74.5 & 13.94 \\
\hline 4 & 62 今 & 12 & $\begin{array}{l}0.6 \\
0.06\end{array}$ & H & 86.6 & 15.52 \\
\hline 5 & 56 今 & 13 & $\begin{array}{l}0.6 \\
0.04\end{array}$ & $H$ & 69.3 & 13. 92 \\
\hline & 56 今 & 4 & $\begin{array}{l}0.4 \\
0.4\end{array}$ & $H$ & 79. 2 & 13.27 \\
\hline & 60 今 & 11 & $\begin{array}{l}0.7 \\
0.02\end{array}$ & H & 74.6 & 15.29 \\
\hline & & & & & * $76.3 \pm 5.71$ & $14.39 \pm 0.77$ \\
\hline & & & & control & $54.7 \pm 4.20$ & $8.89 \pm 1.54$ \\
\hline & & & & $\mathrm{t}=8$ & $\begin{array}{l}\mathrm{n}=14 \\
<0.01\end{array}$ & $\begin{array}{l}=8.07 \mathrm{n}=14 \\
* * \mathrm{p}<0.01\end{array}$ \\
\hline
\end{tabular}

の共通所見がある.すなわち網膜の出血, 浮腫 および軟性白斑は全例にみられ，乳頭の変化と しては血管新生が 4 例, 萎縮が 2 例にみられて おり，血管系の変化としては細動脈の硬化性変 化が 6 例に，乙とに小動脈の白線化が 4 例にみ られとの領域に著明な retinal ischemie のみら れたととは特記すべき所見であった（後述）. 眼圧は全例正常範囲で，scott 分類上からは II b に属し，1眼のみが軽い硝子体出血が認められ た。

\section{II. 全身検查成績の共通点}

表 2 に示したごとく注目される点は動脈性血 管合併症が高率に認められることであった．高 血圧の合併は 7 例中 6 例に，尿蛋白は 5 例にみ られ臨床的糖尿病性腎症も考えられ，またクレ チアニンおよび BUN の測定值からみると軽度 の増量があり腎障害む加味されている.

これらに反し血糖值コントロールは比較的良 好に維持され，血中総コレステロールす正常範 囲に属するすのが多い (No. 2, 4, 5, 6, 7 ).

Goldmann perimeter による視野は全例に何 等かの異常を認め, とくに小イソプタによる部 分的視野の沈下と狭窄を認めるものが多く，小 イソプタで中心暗点を 4 例 (No. $1 ， 2 ， 4 ， 7$ )
に認めた。このような視野の部分的沈下や中心 暗点の出現は網膜病変による，とくに後極部の 所見と対応するものと考えられる.

\section{III. 本網膜症における retinal ischemie の諸相}

本網膜症における蛍光眼底写真の有する臨床 的意義は次のごとくに考えられている.

1）検眼鏡あるいは眼底写真におけるより多く の毛細血管瘤を証明し得るとと. 眼底写真で 発見できないものであ蛍光眼底写真によって 発見し得るととのあるととである。

2）毛細血管あるいは主幹血管の透過性亢進を 知り得ること. これは正常の場合にはフルオ レスセイン液は血管壁から蛍光の漏出はみら れないが，壁透過性㠵進のみられるときは蛍 光の漏出を認めることができる.

3）毛細血管床における無血管帯を知るととが できるとと.これも検眼鏡や眼底写真からで は全く予測し得ないが，蛍光眼底写真によっ て蛍光の non perfusion area として 確認す ることができるとと.

等である.1) は網膜症の早期発見に 2) および 3）は網膜症の進行性を知る上に極めて重要な 所見で臨床的意義は高く評価される， 


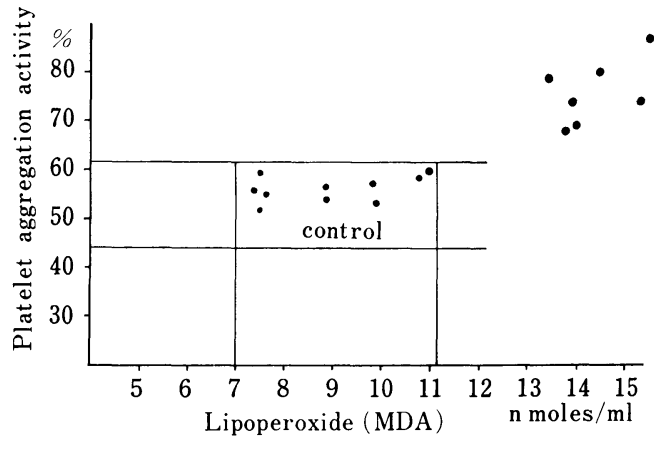

Fig. 2 Ischemic diabetic retinopathy Lipoperoxide (MDA) and Platelet aggregation activity.

一般に本網膜症にみられる retinal ischemie は眼底の後極部に好発する散在性の小さい無血 管帯として知られており，大きくても乳頭大の あのであると報告されている．乙の大部分は毛 細血管系の閉塞によると考えられる.

今回著者らの報告例は眼底の $1 / 4$ 象限ないし $1 / 2$ 象限以上にわたる大きくかつ広範囲にわた る無血管带領域の存在するあのであり, 従来ま であまり報告に接してしない，乙れらは先に眼 底所見の共通点において述べたごとく, その領 域には小動脈あるいは precapillary arteriole の 白線化が認められ，したがっててれらの動脈系 の閉塞と考えられる. 図表の制限のため症例の 蛍光眼底写真は提示できないが shema に示す と Fig.1のごとくで, 今回の症例は図の中で I および II に相当するものである.

\section{VI. 血小板凝集能（\%）と過酸化脂質}

症例ならびに対照者の血小板凝集率および MDA 測定值は表 3 亿示した，対照者は年秢50 歳前後の者で健康者 9 名である．表によると対 照の血小板凝集能は54.7士4.20\%で，MDA は $8.89 \pm 1.54 \mathrm{n} \mathrm{mols} / \mathrm{m} l$ であり, 症例の血小板凝 集能76. $3 \pm 5.71 \%$ および MDA 值 $14.39 \pm 0.77$ $\mathrm{n}$ moles $/ \mathrm{m} l$ で $\mathrm{p}<0.01$ で有意の増加を示して おった. retinal ischemie の程度別では（卅）が 2 例 (H) が 5 例であるので少数例のため統計 的比較はできないが，(H) の方が増加の傾向 を示した．以上の対照並びに症例の血小板凝集 能および MDA 值の実測值をプロットしたも のがFig.2 である. 血小板凝集能と過酸化脂質
の増加の相関についてはさらに症例を増して検 討したいと思う。

\section{V. 考按}

本網膜症に打ける大かつ広範な retinal ischemie についての報告は極めてすくなく, 最近の 報告で Bresnick のものがあるにすぎない，同 氏は retinal ischemie in diabetic retinnopathy と題して 8 例報告している。 そ机によると性別 では 8 例中 7 例と男子に多い点之罹病期間が 10 年以上である点が本実験例と一致するが，年齢 的には20 30歳代以上の屯のが多く, 50歳代以 上のものが 1 例のみなる点が異なっている.

眼底所見として本実験例と共通している点は 網膜症として Scott III b IN の病期に入ると 之, 乳頭上の血管新生の多い点, 網膜血管系は 硬化性変化が強く, 小動脈の白線化のみれたも のが多い点, 視野の変化の合併している点があ げられる。異なる点は虹彩の rubeosis および 網膜上の血管新生の多い点と眼圧が上昇し 縁内 障を呈するあのが多い点であった。

著者らの症例では眼圧は全例共正常であり虹 彩 rubeosis は 1 例もみられなかった。また全身 的な面をみると高血圧の合併は 8 例中 5 例, 血 中クレアチニンは 8 例中 6 例に $5.4 \sim 1.5 \mathrm{mg} \%$ と上昇し，BUN屯同様に 6 例に60 26mg\% と 増量しており，動脈性血管合併症乙腎機能の軽 度の低下を認めている点は著者の症例について 屯軽度ながら共通する点であった。

このように動脈性の血管合併症とくに腎の機 能並びに azotemic の factor ととの大きな retinal ischemie 発生との因果関係は直ちに結 論的なととはいえないにしても，細動脈の硬化 があってさらにそれに何等の trigger としての 要因, 例えば次に述べる血小板凝集能の六進や 過酸化脂質の増加と相まって小動脈あるいは前 毛細血管小動脈の閉塞がきたしたと考えるとと あ容易に想像されるところであろう.

次に本網膜症における血小板凝集能について は Dobbie の研究がみこれる，それによると本 網膜症を 4 群に程度分類して血小板凝集能を測 定し, 網膜症の重症度と血小板凝集能の増加は 相関係数 $+0.778(\mathrm{p}<0.01)$ で有意であったと 
述べ糖尿病性の血管症の病因の 1 つとして血小 板凝集の役割を強調している.

広瀬らは糖尿病性血管障害に対する血液レオ ロジー的アプローチとして Born-O'Brien 法変 法にて血小板凝集率を測定し, 網膜症の scott 0 - II 期では平均 $35 \% ，$ III 期以上では $70 \%$ で有 意の増加を認めたとし, 岡部らも同様の報告を している．著者らすすでに糖尿病患者 41 名につ き血小板凝集率を検討し, 非網膜群と軽症網膜 群では有意の差はみられないが， II b 群以上群 では diabetic maculopathy む含めて有意の增 加を認めたととを報告し， 網膜症の発症よりは その進行増悪に関与すると述べた.

今回対象とした症例は網膜症においても特殊 な重症例であり, すでに述べたごとく血小板凝 集率は $76.3 \pm 5.71 \%$ と極めて高值を示した。

これは網膜における無血管带の増大は血小板 凝集率と相関連することを物語るものであり興 味ある所見と考える.

一方本網膜症における過酸化脂質についての 報告は極めてすくない．上田は八木法に準じて MDA 值を測定し糖尿病患者血清は正常者に比 し有意に高くみられたが，有網膜症群のうち I 一II 期の軽症群と III 期以上の重症群では後者に 高い傾向を認めたが有意差はなかったとし，む しろ罹病期間の長くかつ高血圧および蛋白尿を 伴った症例は高値を示したと述べている．今回 著者の症例は先に述べたごとく全身性動脈血管 合併症例が多く，かつ腎機能も軽度障害されて おり，対照に比し有意の増加を示しておった。

今回の検索でとくに興味深い点は血小板凝集 率のみならず過酸化脂質む有意に増加している ことであった．との点は過酸化脂質は人間の血 小板凝集を六進させるという Mickel らの研究 を想起させて大いに注目したい点である.今後 さらに追究する所存である.

\section{結語}

1. 糖尿病性網膜症における retinal ischemie について蛍光眼底像からその諸相について述 べ, I, II , II 型に分類した.

2. 実験対象例は retinal ischemie のうち I お
よび II 型に属するあの 7 例である.

3. これらの症例には相共通する眼底所見を有 し，全身的にも動脈性血管合併症を有するも のが多く, 腎機能も軽度障害されているもの が多い.

4. 血小板凝集能および過酸脂質は共に元進し 病変の増悪および retinal ischemie 発症の大 きな要因と考えられ, 局所血管内凝固症候群 の一つの病像であろうと思われた.

\section{文献}

1) 石川 清: Diabetic maculopathy の病型と治 療について. 眼科, 17;923 930, 1975.

2) Dobbie, J.G., Kwaan, H.C., Colwell, J.A., and Suwanwela, N.: Role of platelets in pathogenesis of diabetic retinopathy. Arch. Ophthal., 91 ; 107 109, 1974.

3) Bresnick, G.H. et al.: Retinal ischemia in diabetic retinopathy. Arch. Opthal., 93; 1300 1310, 1975.

4）上田準一： 糖尿病性網膜症における過酸化脂 質について. 日眼, 73；1367〜1378， 1969.

5）佐藤和雄, 高久 功： 糖尿病における血小板 粘着能について. 日本眼科紀要, $27 ; 750$ 753, 1976.

6) Kwann, H. C., Colwell, J. A. and Suwanwel, N.: Disseminated intravascular coagulation in diabetes mellitus, with reference to role of increased platelet aggregation. Diabetes, $21 ; 108 \sim 113,1972$.

7) 石川 清：シンポジウム一糖尿病性網膜症一 臨床像について, II-3, 黄斑部病変とその対 策. 日眼, $80 ； 1491 \sim 1513,1976$.

8）忍足正之, 島野葉子, 大塚 裕, 石川 清: 血液凝固系から網膜循環障害へのアプローチ (1). 臨眼, 投稿中.

9）木村重男, 新井公文: 網膜静脈閉塞症におけ る血小板凝集能. 日眼, 79; 1753 1757, 1975.

10）広瀬伥男, 他：糖尿病性血管障害に対する血 液レオロジー的アプローチ(9), 血小板凝集能 のむつ意義. 糖尿病, 18; 57, 1975 (Supple).

11）岡部和彦, 他：糖尿病の血液凝固機転. 糖尿 病, 19;107 109, 1974. 